UTILIZATION OF CALIFORNIA DESERT HABITAT TYPES

OF BIRDS IN SECTION 9 AND 10 OF LANFAIR VALLEY, CALIFORNIA

1978

by

Barbara A. Car1son

P.O. Box 1015

Upland, California 91786

for

Bureau of Land Management

1695 Spruce Street

Riverside, California 92507

Contract CA-060-CT8-57 

JOSHUA TREE WOODLAND - 10 - -- Location: Califorria, San Bernaraino Co., Lanfair Valley, $5.3 \mathrm{mi} N$ of Cedar Cyn Rd., $4.0 \mathrm{mi}$ E of Ivanpah Rd. The Dlot is in the $E 1 / 2$ of the $I W 1 / 4$ and $W 1 / 2$ of the $N E 1 / 4$ of Sec. 10 , T13N, R17E, Lanfair Valley Quadrangle, USGS; $35^{\circ} 14^{\prime} \mathrm{N}, 115^{\circ} 8^{\prime} \mathrm{w}$. The NW corner is approximately $75 \mathrm{~m} \mathrm{~S}$ and $110 \mathrm{~m}$ W of the USGS Sec. 3/Sec. $101 / 4$ marker. Continuity: Niew. Size: 20 ha $=49.42$ acres, (rectangular $500 \mathrm{~m} \times 400 \mathrm{~m}$, measured). Description of Plot: Typical Joshua Tree Woodland that is found in the northern portion of the valley. Vegetation: Five (5) 100 toe-point transects were made to determine percent cover and species composition. The substrata consisted of $48.6 \%$ bare ground, $36.0 \%$ litter, $9.2 \%$ small rocks $(<5 \mathrm{~cm}), 4.2 \%$ shrub stems, and $2.0 \%$ large rocks $(>5 \mathrm{~cm})$. Small and large shrubs and perennial grasses formed a canopy cover and ground cover of $16.8 \%$. Composition of perennial plants included $29.0 \%$ Galleta Grass (Hilaria rigida), $15.2 \%$ Little-Leaved Ratany ('Krameria Darvifolia), 9.2\% Creosote Bush (Larrea tridentata), $7.6 \%$ Goldenhead (Acamptonapous sphaerocephalus), $7.2 \%$ Cheese Bush (Hynenoclea salsola), 5.2\% Black-banded Rabbit Brush (Chrysothamnus Daniculatus), $4.8 \%$ Hop-Sage (Gravia spinosa), 3.0\% Wormon Tea (Ephedra nevadensis), 2.8\% Cooper Goldenbush (Haplopappus cooperi), $2.4 \%$ Woollyfruited Burbush (Ambrosia eriocentra), 2.0\% Wild-Rhubarb (Rumex hymenosepalus), $1.8 \%$ Burro-weed (Ambrosia dumosa), 1.6\%.Ricegrass (Orvzopsis hymenoides), 1.0\% each of Desert Mallow (Sphaeralcea ambigua), and Buckhorn Cholla (Opuntia acanthocarpa), $0.8 \%$ each of Bladder-sage (Salazaria mexicena), and Winter Fat (Eurotia lanata), 0.6\% each of Cooper's Eoxthorn (Ivcium cooperi), Hojave Yucca (Yucca schidirera), and Purple Sage (Salvia dorrii), $0.4 \%$ each of Grizzly Bear Cactus (Oountia erinacea, var. ursina), and Joshua Tree (Yucca brevifolia), 0.2, each of 
Matchweed (Gutierrezia microcenhala), California Buckwheat (Eriogonum fasciculatum), Four-c'Clock (Mirabilis froebelii), Desert-Aster

(Machaeranthera tortifolia), Paper Flower (Psilostrophe cooperi), Desert Almond (prunus fasciculata), Spanish Eayonet (Yucca baccata), Cotton Thorn (Tetradymia axillaris), Desert Trumpet (Eriogonum inflatum), and Jimsonweed (Datura meteloides). Plant names are from Philip A. Munz, A Flora of Southern California, 1974. The area has a long history of livestock grazing, which probably has affected the composition of the understcry. It has not been grazed this year. Elevation: $4100 \mathrm{ft}(1250 \mathrm{~m})$. Edge: The plot is bounded on all sides by Joshua Tree Woodland community. There is a dirt road $75 m-100 \mathrm{~m}$ south of the plot frequently used by local ranchers. Tonomaphy: Basically flat with one wide, but shallow wash extending from the $\mathrm{NW}$ to the $\mathrm{SE}$ in the southern half of the plot. Water: The nearest permanient water is a livestock water tank located approximately 150 $\mathrm{m}$ of the SW corner. Heather: Temperatures during the study period ranged from $57^{\circ} \mathrm{F}$ to $91^{\circ} \mathrm{F}$ with no precipitation recorded. Coveraze: June $10,14,21,23,24,26,28,30$. Total: 8 trips, all between 0445 and 1000 PST. Total Man-hours: 29.0. Census: Mourning Dove, $8(40,16)$; Black-throated Sparrow, $4.5(23,9)$; Ash-throated Flycatcher, 2.5 (13.5); Verdin, 2(10,4); Cactus Wren, 2; Cambel's Quail, $1.5(8,3)$; Lockingbird, 1.5; Loggerhead Shrike, 1.5; Bendjre's Thrasher, 1 (5,2); LeConte's Thrasher, 1; Black-taileà Gnatcatcher, 1; House Finch, 1; Brewer's Sparrow, 1; Common Flicker-Gilded Race, .5; Red-tailed Hawk, t; American Kestrel, +; Ladder-backed Woodpecker, +; Western Kingbird, +; Erown-headed Cowbind, +. Total: 19 species; 29 territorial males or females $\left(145 / \mathrm{km}^{2}, 59 / 100\right.$ acres $)$. Visitors: Turkey Vulture, Swainson's Hawk, Golden Eagle, Lesser Wighthawk, Say's Phoebe, Horned Lark, Cliff Swallow, Lark Bunting. Iate Migrant: Western Wood PeeWee. 
Remarks: 3 active nests were found; 1 each of Ash-throated Flycatcher, Cactus Wren and House Finch. A Hawk nest believed to be the Red-tailez Hawk's nest used this year was also found. The following were observed feeding fledglings just out of the nest; Ladker-backed Woodpecker, Western Kingbird, Ash-throated Flycatcher, Verdin, Black-tailed Gnatcatcher (feeding fledgling Brown-headed Cowbird), Black-throated Sparrow, Erewer's Sparrow. Two evenings were spent listenine and watching for owls and goatsuckers. A Lesser Nighthawk was observed on one of the evenings. Poorwills were observed within .5 $\mathrm{mi}$ of the plot and probably use the area. The female Comron Flicker had yellow shafts and male and juveniles observed had red shafts. The count on the Mourning Dove is average number of pairs observed on the plot and may be incorrect as doves were flying from surrounding area to the water tank near the southwest corner of the plot. The following mammals and reptiles were observed on the plot durins the surveys (numbers indicates total number of observations); Black-tailed Jack Rabbit (Lepus californicus), 40; Desert Cottontail (Silvalazus auzuboni), 3; White-tailed Antelope Squirrel (Ammospermophilus leucurus), 16; Desert Woodrat (Iieotoma lepida), 1; Western Whiptail Lizard (Cnemidoporus tigris), 33; Zebra-tailed Lizard (Callisaurus araconoides), 14; Desert Spiny Lizard (Sceloporus magister), 8; Leopard Lizard (Crotaphytus wislizenii), 1; Side-blotched Lizard (Uta stansburizna), 3. We wish to thank Ruth C. Yoder and Rolland H. Vissler for assistance given during the survey. This study was sponsored by the Bureau of Land Management, California Desert Plan Program. BAPRARA A. CARLSOH, P.O. Box 1015, Upland, CA. and SHELION J. NEHEERGER, 978-A Springfield Ave., Upland, CA. 

JOSHU TRE WOODLAND -- Location: California, San Eernaraino Co., Lanfair Valley, $5.3 \mathrm{mi} N$ of Cedar Cyn. Rd., $4.0 \mathrm{mi}$ E of Ivanpah Rd. The plot is in the $\Xi 1 / 2$ of the NW $1 / 4$ and $W 1 / 2$ of the $N E 1 / 4$ of Sec. 10, T13N, R17E, Lanfair Valley Guadrangle, USGS; $35^{\circ} 14^{\prime} \mathrm{N}, 115^{\circ} 8^{\prime} \mathrm{W}$. The $N$ corner is approximately $75 \mathrm{~m} \mathrm{~S}$ and $110 \mathrm{~m} \mathrm{~W}$ oI the USGS Sec. 3/ Sec $101 / 4$ marker. Continuitv: See Ereeding Bird Survey, 1978. Size: $20 \mathrm{ha}=49.42$ acres, (rectangular $500 \mathrm{~m} \times 400 \mathrm{~m}$, measured). Description of Plot: Typical Joshua Tree Woodland that is found in the northern portion of the valley. Weather: Temperatures durins the study period ranged from $54^{\circ}$ to $98^{\circ} \mathrm{F}$. Very little precipitation was recorded as the normal summer rains were light and sporadic in Eround coverage. Coverage: Jul 20, 22, Aug 4, 6, Sep 9, 10. Total: 6 trips, all between 0450 and 0900 PST, averaging 183 minutes each. Count: Iinon Jay, 59 (295, 119); Hourning Dove, 38 (190, 77); Gambel's Quail, $17(85,34)$; House Finch, 17; Black-throated Sparrow, $13(65,26)$; Cactus Wren, $6(30,12)$; Ladder-backed Woodpecker, $2(10,4)$; Loggerhead Shrike, 2; Brewer's Sparrow, 2; American Kestrel, 1 (5, 20; Common 'Gilded' Flicker, 1; Barn Swallow, 1; Verdin, 1; LeConte's Thrasher, 1; Cooper's Hawk, +; Marsh Hawk, +; Red-tailed Hawk, +; Poorwill, +; Roadrunner, +; Ash-throated Flycatcher, +; Western Kingbird, +; Tree Swallow, +; Horned Lark, +; Bendire's Thrasher, +; Black-tailed Gnatcatcher, +; Erown-headed Cowbird, +; Scott's Oriole, +; Lark Sparrow, +. Total 28 species, 161 (805/ $\mathrm{km}^{2}, 326 / 100$ acres). Remarks: Ash-throated Flycatcher, Nestern Kingbird, Bendire's Thrasher, Black-tailed Gnatcatcher, Brown-headed Cowbird and Scott's Oriole are breeding/summer residents who migrated out sometime durins the census period and therefore the numbers reflacted are loken than normal. 
Pinon Jays observed are probably flock invasions that occur in fall and winter from surrounding mountains. The Barn Swallow and Tree Swallow are fall migrants. The Cooper's Hawk, Marsh Hawk, and Lark Sparrow are either fall migrants or wintering residents that arrived during the census period. The plot continues to have more species and individuals than the plot in Sec. 9. There has been some grazing since June but not much. The watering tank to the SW of the plot is probably the attractant force for the Gambel's Quail, Mourning Dove, and House Finch as the area becomes dryer. We wish to thank Ruth C. Yoder and Steve Knuttel for assistance given on the surveys. This study was sponsored by the Bureau of Land Management, California - Desert Plan Program. BARBARA A. C.RLSON, P. O. Box 1015, Upland, CA 91786, and SHELDON J. NEWBERGER, 978-A Springfield Ave., Upland, CA 91786. 
JOSHUA TREE WOODLAND -- Lecatian: California, San Bernardino Co., Lanfair Valley, $5.3 \mathrm{mi} \mathrm{N}$ of Cedar Cyn Rd., $4.0 \mathrm{mi} \mathrm{E}$ of Ivanpah Rd. The plot is in the E $1 / 2$ of the NW $1 / 4$ and $W 1 / 2$ of the $\mathrm{NE} 1 / 4$ of Sec. 10 , T13N, R17E, Lanfair Valley Quadrangle, USGS; $35^{\circ} 14^{\prime} \mathrm{N}, 115^{\circ} 8^{\prime} \mathrm{h}$. The IW corner is approximately $75 \mathrm{~m} \mathrm{~S}$ and $110 \mathrm{~m} \mathrm{~W}$ of the USGS Sec. 3/Sec. $101 / 4$ marker. Continuitv: See Breeding Bird Survey 1978. Size: 20 ha = 49.42 acres, (rectangular $500 \mathrm{~m} \times 400 \mathrm{~m}$, measured). Description of plot: Typical Joshua Tree Woodland that is found in the northern portion of the valley. Weather: Temperatures during the study period ranged from $32^{\circ}$ to $84^{\circ} \mathrm{F}$. Precipitation of both rain and snow fell during November and December. Coverage: Oct 8, 14, Nov 18, 26, Dec 3, 11, 1978. Total: 6 trips, all between 0600 and 1030 , averaging 184 minutes each. Count: House Finch, 26(130, 53); Black-throated Sparrow, $9(45,18)$; Gambel's Quail, $7(35,14)$; Mourning Dove, 5(25,10); Cactus Wren, $4(20,8)$; Sage Sparrow, $3(15,6)$; Common (Gilded) Flicker, 1 (5, 2); Ladder-backed Woodpecker, 1; Verdin, 1; LeConte's Thrasher, 1; Loggerhead Shrike, 1; Yellow-rumped (Audubon's) Warber, 1; Golden Eagle, +; Swainson's Hawk, t; Prairie Falcon, +; American Kestrel, +; Roadrunner, +; Great Horned Owl, +; Common Raven, +; Pinyon Jay, +; Blue-gray Gnatcatcher, +. Average total: 60 birds $\left(300 / \mathrm{km}^{2}, 121 / 100\right.$ acres $)$ Remarks: 21 species. Hunters were present on and near the plot during the 18 Nov census, unfortunate but unavoidable. I believe the hunting not only had an effect on the number of Gambel's Quail present thereafter, but also on the other passerine species, not necessarily shooting them, but driving them back into areas not hunted, away from the plot itself. I thank Ruth C. Yoder for assistance given during the survey. This study was sponsored by the Bureau of Land Management, California Desert Plan Program. BARBARA A. CARLSON, P. O. Box 1015, Upland, CA 91786. 

Nethods Used:

Bird Surveys: The surveys were conducted by slowly walking thru the plot at approximately $100 \mathrm{~m}$ intervals along the length of the plot (see

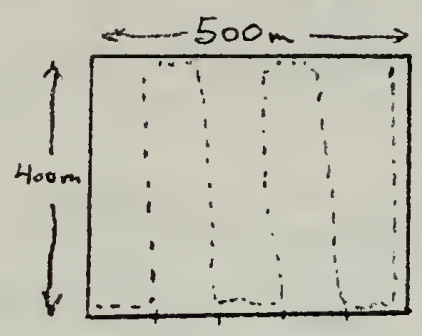

diagram). The only stops made were occasional observations that we thought might lead to nests, etc. When more than one person was along one did the identification and the other the recording.

One point of interest - in order to meet the deadline of the end of June we had to census on consecutive days two times. The second day turned out to be one of the lowest count days each time. It may be a coincidence, but it appears that allowing at least one day between is a better method for recording the maximum number of birds.

Determining territories was difficult - when juveniles are out of the nest the territories tend to break down. The spot-maps were used to determine territories for all species except doves. The actual count of doves is much higher because the plot is in the "flyway" to the water tank. I went back to the maps and attempted to deternine those doves that moved from within the plot, then used ore-half as the number of territorial pairs. For the maps 3 different jays recorded constituted a territory in keeping with the standards from American Birds.

The Flickers, according to Grinnell, Miller \& Peterson, with the redish shafts are probably Gilded. Flickers - they have the two forms, rather than being the red-shafted race interbreeding with the gilded race. I have treated them as all gilded race. 
Veget tion Analvsis: The five 100 toe-point transects were run starting at approximately the $50 \mathrm{~m}, 150 \mathrm{~m}, 250 \mathrm{~m}, 350 \mathrm{~m}$ and $450 \mathrm{~m}$ points along the length edse. A toe-point was taken at every 6 th pace which was approximately $4 \mathrm{~m}$ so the lines crossed the plot. One paced and one recorded. We alternated after each 100 toe-point transect in recording and pacing.

However, I Delieve that belt transects would give a truer picture of the vegetation here because of the large differences between cover of a clump of Hilaria and of the shrubs. Belt transects would probably give a clearer picture of the grazing effects also. 
JOSHUA TREE WOODAND - 9 -- Location: California, San Berrardino Co., Ianfair Valiey, $(5.4 \mathrm{mi}$ is of Cedar Cyn Rd), $2.8 \mathrm{mi} \mathrm{E}$ of I vanpah Rd. The plot is in the $1.1 / 4$ of Sec. 9, T13N, R17E, Lanfair Valley quadrangle, USCS; $35^{\circ} 14^{\prime} \mathrm{l}, 115^{\circ} 8 \mathrm{H}$ Continuity: New. Size: 20 ha $=49.42$ acres, (rectansular $500 \mathrm{~m} \times 400 \mathrm{~m}$, measured). Description of Plot: A typical Joshua Tree Woodland community of the northern portion of the valley. Joshua trees are scattered over the plot with a concentration near the middle of the west edge. Vegetation: Five (5) 100 toe-point transects were made to detemine percent cover and species composition. The substrata consisted of $40.6 \%$ bare ground, $30.4 \%$ litter, $14.2 \%$ small rocks $(<5 \mathrm{~cm})$, 12.2\% scrub stems and 2.6\% large rocks $(75 \mathrm{~cm})$. Small and large scrubs and perennial grasses formed a canopy cover and ground cover of $21.8 \%$. Composition of perennial plants included $41.0 \%$ Galleta Grass (Hilaria rigida), $11.11 \%$ Cooper's Goldenbush (Haplopappus cooperi), $9.0 \%$ Burroweed (Ambrosia dumosa), 7.2\% Hop-Sage (Gravia soinosa), 5.4\% Creosote Bush (Larrea tridentata), 5.0\% Matchweed (Gutierrezia microcephala), 3.0\% Desert Mallow (Sphaeralcea ambigua), 2.8\% Goldenhead (Acamptopapnus Sphaerocenhalus), 2.0\% Cheese Bush (Hymenoclea salsola), $1.4 \%$ each of Woolly-fruited Burbush (Ambrosia eriocentra), and Hoffmansezoia densiflora, 1.2\% each of Winter Fat (Eurotia lanata), Mormon Tea (Ephedra nevadensis), and Iittle-leaved Ratany (Krameria parvifolia), 1.0\% Purple Sage (Salvia dorrii), .8\% Ricegrass (Oryzopsis hymenoides), .6\% each of Buckhorn Cholla (Opuntia acanthocarpa), and Desert Trumpet (Eriogonum inflatum), $.4 \%$ each of Four O'Clock (Mirablis froebelii), Rroom Twinberry (Menociora sconaria), Spanish Bayonet (Yucca baccata), Bladder-sare (Salazaria mexicana), Mohave Yucca (Yucca schidigera), Desert Willow (Chilopsis linearis), Wild-Rhubarb (Rumex hymenosepalus), and $.2 \%$ each of Cooper's 
Boxthorr (Ivcium cooderi), Desert Almond (Prunus fasciculata), DesertAster (Machaeranthera tortifolia), California Buckwheat (Eriogonum fasciculatum), and Paperflower (Psilostrophe cooperi). Plant names are from Philip A. Munz A Flora of Southern California, 1974. The area has a long history of livestock grazing, which probably has affected the composition of the understory. It has not been grazed this year. Elevation: $4180 \mathrm{ft}(1274 \mathrm{~m})$. Edge: The plot is bounded on all sides by Joshua Tree Woodland with a wide but shallow wash near the east side and a dirt road that had not been used for a few years running approximately 25-75m to the south of the plot. Topography: Basically flat with moderately wide but shallow wash running from the $\mathrm{NW}$ to the SE across the $\mathrm{S}$ half of the plot. Water: The nearest permanent water are livestock waterine troughs and tank, one $1.2 \mathrm{mi} \mathrm{SW}$ and one $1 \mathrm{mi} E$ of the plot. Weather: Temperatures during the census ranged from $57^{\circ} \mathrm{F}$ to $91^{\circ} \mathrm{F}$. No precipitation was recorded. Coverage: June 11, 15, 22, 24, 25, 27, 29, 30. Total: 8 trips, all between 0430 and 0900 PST. Total Man-hours: 27.5 . Cersus: Mourning Dove, 7 (35,14); Black-throated Sparrow, $5.5(28,11)$; Ash-throated Flycatcher, $2(10,4)$; Mockingbird, 2; Gambel's Quail, 2; Loggerhead Shrike, 2; Cactus Wren, 1.5 (8.3); LeConte's Thrasher, 1 (5.2); Scott's Oriole, 1; Horned Lark, .5; Bendire's Thrasher, .5; Red-tailed Hawk, +; Common Flicker-Gilded Race, +; Total: 13 species; 25 territorial males or females $\left(125 / \mathrm{km}^{2}, 51 / 100\right.$ acres). Visitors: Turkey Vulture, American Kestrel, Ladder-backed Woodpecker, Say's Phoebe, Common Raven, Verdin, Hountain Bluebird, Western Meadowlark, House Finch, Black-chinned Sparrow, Brewer's Sparrow. Remarks: 8 active nests were found; 5 Mourning Dove, 1 each of Ash-throated Flycatcher, Cactus Wren and Horned Lark. Two evenings were spent listening and watching for owis and coatsuckers without success. However, Poor-wills were observed foraging 
less than $.5 \mathrm{mi}$ from the plot and probably use the area. The count on the Mourning Doves is the average number of pairs observed on the plot but is probably close to the real number of breeding pairs since 5 active nests were found. A pack of ourros went thru the plot during the night of Jun 29. Other mammals and reptiles observed during the census were (numbers indicate total numbers of observations): Elack-tailed Jackrabbit (Lepus californicus), 46; Desert Cottontail (Silvalagus auduboni), 20; White-tailed Antelope Squirrel (Ammospermophilus leucurus), 3; Desert Woodrat (Neotoma lepida), 3; Coyote (Canis latrans), 1; Western Whiptail Iizard (Cnemidonorus tigris), 50; Desert Spiny Lizard (Sceloporus magister), 3; Zebra-tailed Lizard (Callisaurus droconoides), 5; Desert Horned Lizard (Phrynosoma nlatyrhinos), 3; Side-blotched Lizard (Uta stansburiana), 4; and Leopard Lizard (Crotaphytus wislizenii), 3. We thank Ruth $\mathrm{C}$. Yoder and Rolland $\mathrm{H}$. Wissler for assistance given during the survey. This study was sponsored by the Bureau of Land Management, California Desert Plan Program. BAREARA A. CARLSON, P.O. Box 1015, Upland, CA. and SHELDON J. NEIBERGER, 978-A Springfield A.ve., Upland, CA. 

JOSHUA TREE WOODLAID -- Iocation: California, San Eernariino Co., Ianfair Valley, $5.4 \mathrm{mi}$ N of Cedar Cyn. $\mathrm{Pd}, 2.8 \mathrm{mi} \mathrm{E}$ of Ivanpah Rd. The plot is in the $W$ 1/4 of Sec. 9, T13N, R17E, Lanfair Valley Euazinanfle, USGS; $35^{\circ} 14^{\prime} \mathrm{N}, 115^{\circ} 8 \%$ Continuitv: See Ereeding Bird Survey, 1978. Size: 20 ha $=49.42$ acres, (rectangular $500 \mathrm{~m} \times 400 \mathrm{~m}$, measured). Descriotion of Plot: A typical Joshua Tree Woodland community of the northern portion of the valley. Weather: Temperatures during the census ranged from $63^{\circ}$ to $98^{\circ} \mathrm{F}$. Very little precipitation was recorded as the normal sumner rains were light and sporadic in coverage. Coverace: Jul 21,23, Aug 5, 7, Sep 4, 10. Total: 6 trips, all betwreen 0440 and 0845 PST, averaging 198 minutes each. Count: Black-throated Sparrow, $25(125,51)$; Mourning Dove, $18(90,36)$; House Finch, 5 (25, 10); Pinon Jay, 5; Cactus iren, 4 $(20,8)$; Gambel's Quail, $3(15,6)$; Ash-throated Flycatcher, 3; Loggerhead Shrike, 3; Lejonte's Thrasher, 2(10, 4); Scott's Oriole, $1(5,2)$; Turkey Vulture, +; Red-tailed Hawk, +; Great Horned Owl, +; Poorilil, +; Common 'Gilded' Flicker, +; Laddor-backed Woodpecker, +; Say's Phoebe, +; Verdin, +; Eewick's Wren, t; Mockingbird, t; Crissal Thrasher, +; Brewer's Sparron, +. Total 22 species, $69\left(345 / \mathrm{km}^{2}, 140 / 100\right.$ acres). Remarks: Ash-throated Flycatcher and Scott's Oriole are breeding/ summer residents who migrated out sometime during the census period and therefore the numbers reflected are lower than normal. Pinon Jays observed are probably flock invasions that occur in fall and winter from the surrounding mountains. No true midrants were observed. This plot continues to have fewer species and fewer injividuals than the plot in Sec. 10. There has been evidence of increased grazing in this area. Ve wish to thank Ruth C. Yoisn and Steve Knuttel for 
assistance given on the surveys. This study was sponsored by the Bureau of Land hanagement, Desert Plan Program. BAREARA A. CARISON, P. O. Box 1015, Upland, CA. 91786 and SHELDON J. NEIEERGER, 978-A Springfield Ave., Upland, CA. 91786. 
JOSHUA TREE WOODLAND -- Lecation: California, San Bernardino Co., Lanfair Valley, (5.4 $\mathrm{mi} \mathrm{N}$ of Cedar Cyn Rd), $2.8 \mathrm{mi} \mathrm{E}$ of Ivanpah Rd. The plot is in the NW $1 / 4$ of Sec. 9, T13N, R17E, Lanfair Valley Quadrangle, USGS; $35^{\circ} 4^{\prime} \mathrm{N}, 115^{\circ} 8^{\prime} \mathrm{W}$. Continuity: See Breeding Bird Survey 1978. Size; 20 ha $=49.42$ acres, (rectangular $500 \mathrm{~m} \times 400 \mathrm{~m}$, measured). Description of Plot: A typical Joshua Tree Woodland community of the northern portion of the valley. Joshua trees are scattered over the plot with a concentration near the middle of the west edge. Weather: Temperatures during the study period ranged from $32^{\circ}$ to $84^{\circ} \mathrm{F}$. Precipitation of both rain and snow fell during November and December. Coverage: Oct 8, 15, Nov 19, 26, Dec 3, 11, 1978. Total: 6 trips, all between 0600 and 1030 PST, averaging 183 minutes eách. Count: Gambel's Quail, 21(105,42); House Finch, 12(60, 24); Sage Sparrow, 7 (35,14); Black-throated Sparrow, 6(30, 12); Loggerhead Shrike, $2(10,4)$; Red-tailed Hawk, 1(5, 2); Ladder-backed Woodpecker, 1; Verdin, 1; Cactus Wren, 1; Bendire's Thrasher, 1; LeConte's Thrasher, 1; White-crowned Sparrow, 1; Golden Eagle, +; Cooper's Hawk, +; Common Raven, +; Common (Gilded) Flicker, +; Bewick's Wren, + . Average total: 55 birds $\left(275 / \mathrm{km}^{2} / 111 / 100\right.$ acres $)$. Pemarks: 17 species. The Gambel's Quail appeared in a large flock on this plot in the middle of November, probably due to the hunting pressure near the roads and tanks. The Bendire's Thrasher did not migrate out until the middle of November. There were fewer House Finches on this plot compared to the one in Sec. 10. Although nc cattle were observed on the plot, there was evidence of grazing on a small scale. I thank Ruth C. Yoder for assistance given during the survey. This study was sponsored by the Bureau of Land Management, California Desert Plan Program. BARBARA A. CARLSON, P. O. BOX 1015, Upland, CA 91786. 



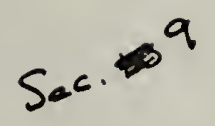

Vetnols Used:

Bird Surveys: The surveys were conducted by slowly walking thru the plot at approximately $100 \mathrm{~m}$ intervals along the length of the plot (see

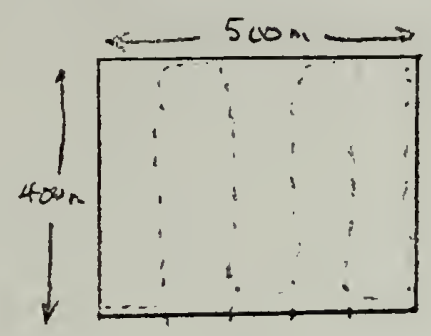

diagram). The only stops made were occasional observations that we thought might lead to nests, etc. When more than one person was along one did the identification and the other the recording.

One point of interest - in order to meet the deadline of the end of June we had to census on consecutive days two times. The second day turned out to be one of the lowest count days each time. It may be a coincidence, but it appears that allowing $a \frac{1}{i}$ least one day between is a better method for recording the maximum number of birds.

Determining territories was difficult - when juveniles are out of the nest the territories tend to break down. The spot-maps were used to determine territories for all species except doves. The doves were calculated by using the average divided by two for number of territorial pairs. Although Verdins and Brewer's Sparrows were seen on at least three occasions each, they were immatures and therefore counted as visitors.

Veetation Analysis: The five 100 toe-point transects were run starting at approximately the $50 \mathrm{~m}, 150 \mathrm{~m}, 250 \mathrm{~m}, 350 \mathrm{~m}$ and $450 \mathrm{~m}$ points alone the length edee. A toe-point was taken at every 6 th pace which was approxinately $4 \mathrm{~m}$ so the lines crossed the plct. One paced and one recorded. We alternated after each 100 toe-point transect in recordirg and pacing. 
However. I believe that belt transects would give e truer picture of the vegetation here because of the large differences between cover of a clump of rilaria and of the shrubs. Belt transects would probably give a clearer picture of the grazing effects also. 


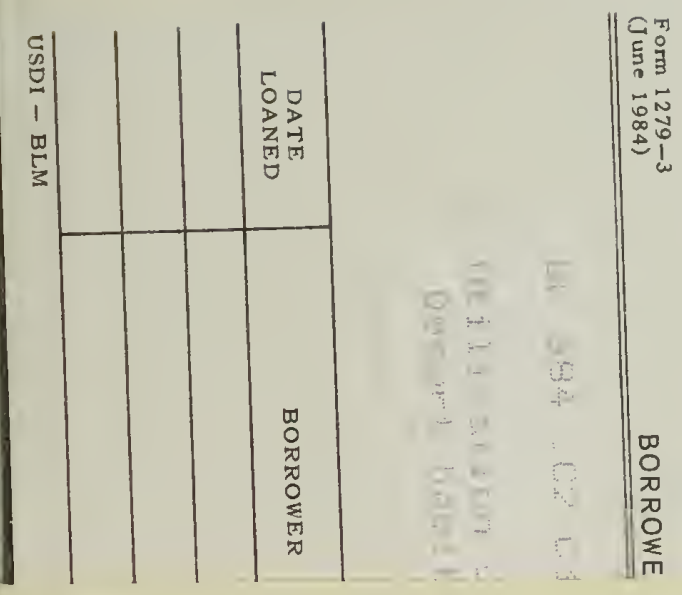

\section{BLM Library}

D-553A, Building 50

Denver Foderal Center

P. 0. Box 25047

Denver, CO 80225-0047 
